\title{
Prehistoric Caddo Ceramics from the Henry Lake Site (41CE324), Cherokee County, Texas
}

Timothy K. Perttula

Heritage Research Center, Stephen F. Austin State University

Tom Middlebrook

Heritage Research Center, Stephen F. Austin State University

Follow this and additional works at: https://scholarworks.sfasu.edu/ita

Part of the American Material Culture Commons, Archaeological Anthropology Commons, Environmental Studies Commons, Other American Studies Commons, Other Arts and Humanities Commons, Other History of Art, Architecture, and Archaeology Commons, and the United States History Commons

Tell us how this article helped you.

This Article is brought to you for free and open access by the Center for Regional Heritage Research at SFA ScholarWorks. It has been accepted for inclusion in Index of Texas Archaeology: Open Access Gray Literature from the Lone Star State by an authorized editor of SFA ScholarWorks. For more information, please contact cdsscholarworks@sfasu.edu. 
Prehistoric Caddo Ceramics from the Henry Lake Site (41CE324), Cherokee County, Texas

\section{Creative Commons License}

\section{(c) (1) \&}

This work is licensed under a Creative Commons Attribution-NonCommercial 4.0 International License 


\title{
Prehistoric Caddo Ceramics from the Henry Lake Site (41CE324), Cherokee County, Texas
}

\author{
Timothy K. Perttula and Tom Middlebrook
}

\section{INTRODUCTION}

This article discusses the character of the Caddo ceramics from a single component Frankston phase (ca. A.D. 1400-1650) occupation at the Henry Lake site (41CE324) in northwestern Cherokee County, Texas. This follows a brief discussion of the history of the site, and we conclude this article with a consideration of the temporal and cultural place of the site's Caddo ceramic assemblage within the upper Neches River basin.

\section{Discovery of the Site}

A Mr. Joe Bob Staton of Jacksonville, Texas, discovered the Henry Lake site in June 1995 during the course of constructing a road on his property that ran from Cary Lake to Henry Lake, paralleling the Neches River floodplain. Caddo ceramic sherds were noted and collected by Mr. Staton's crew in the roadway (Swanson and Middlebrook 1996).

Mr. Staton contacted the chairman of the Cherokee County Historical Commission, John Allen Templeton, about the find, who subsequently notified the Office of the State Archeologist at the Texas Historical Commission. In July 1995, Gladys Swanson and Tom Middlebrook, both Stewards of the Texas Archeological Stewardship Network, visited the site with Mr. Staton, obtained a surface collection of archaeological materials (primarily Caddo ceramics, but also 14 pieces of lithic debris, five small pieces of animal bones, and five pieces of mussel shell), and officially recorded the site. There have been no archaeological investigations at the Henry Lake site since July 1995. In early 2008 , the Caddo ceramics from the site were examined in detail as part of the on-going analysis of Frankston and Allen phase ceramic assemblages in the upper Neches River basin (see Perttula 2008).

The Henry Lake site is on a wooded lower toe slope ( $300 \mathrm{ft}$. amsl) or natural rise landform, overlooking the Neches River floodplain about $1.25 \mathrm{~km}$ east of the current channel of the Neches River; it is ca. $11 \mathrm{~km}$ south of the Lake Palestine dam. The overall extent of the Henry Lake site is estimated at $100 \times 75 \mathrm{~m}$, or 1.85 acres.

There are steep uplands and small mountains paralleling the river floodplain, and these crest at $450 \mathrm{ft}$. amsl atop Cary Lake Mountain, not far south of the site. This area is part of the Boggy Creek salt dome, and the broad floodplain here is marked by several relict channels of the Neches River, including Cary Lake and Henry Lake; this natural lake is ca. $320 \mathrm{~m}$ northwest of the site.

\section{The Henry Lake Site Ceramic Assemblage}

The Henry Lake site Caddo ceramic assemblage consists of 279 sherds, 188 ( 68 percent) of which

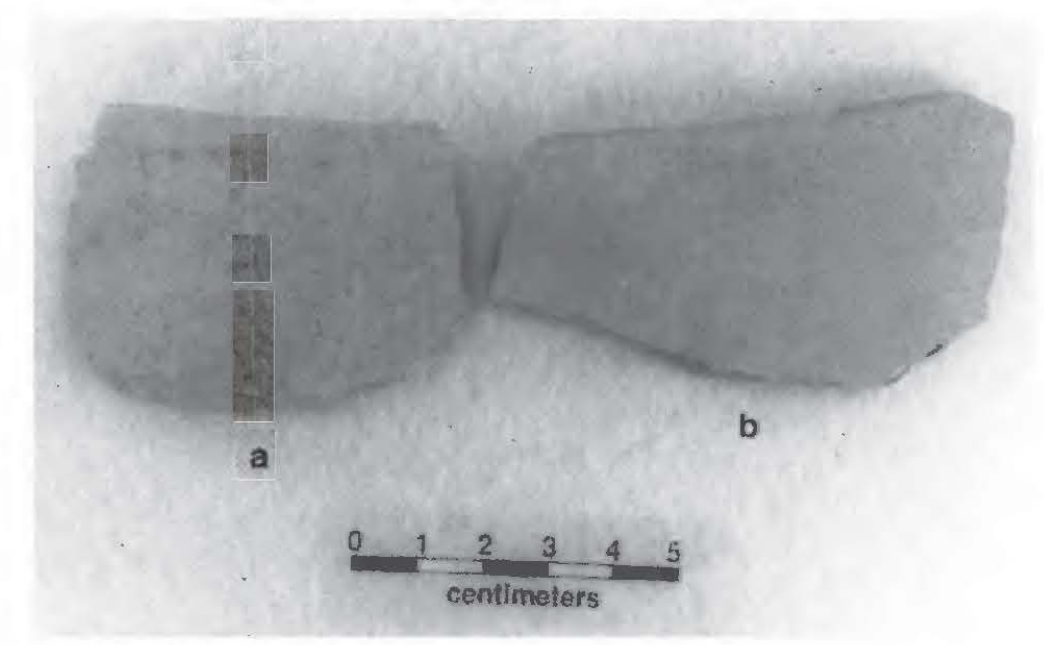

Figure 1. Plain rim sherds. 
have a decorated exterior surface, and the other 91 sherds are undecorated or plain (Appendix 1). The plain sherds include four rinss (Figure la-b), one bottle neck, 79 body sherds, and seven base sherds. The plain/decorated sherd ratio (P/DR) is a low 0.48 .

The decorated shcrds from Henry Lake are dominated by utility wares, coarsely-tempered and relatively thick vesscls that were used for cooking and storage tasks. These utility ware vessels were decorated prior to their being fired (i.e., wet paste decorations). Utility ware decorated sherds comprise $89.4 \%$ of the decorated sherd assemblage (Table 1), but only $41.7 \%$ of the rims. Vessel sherds from decorated fine wares (i.e., thin, well-fired, and finely-tempered, with engraved decorations) account for $10.6 \%$ of the Henry Lake sherds, but $58.3 \%$ of the rims. This disparity in the proportions of total number of utility ware vs. fine ware sherds and the proportions of utility ware and fine ware rims is typical of Late Caddo ceramic assemblages. Late Caddo utility ware vessels are relatively large in size and decorated surface area, and tend to be decorated on both the rim and much of the body (but not always with the same decorative method), and when they are fragmented, they produci sherd assemblages with high ratios of decorated utility ware body sherds to decorated rim sherds (30.6:1 at Henry Lake). The overall smaller fine ware vessels tend to be decorated only on the rim (including the lower part of the rim, here characterized as a body sherd because the lip and much of the upper part of the rim is missing), and decorated body to rim sherd ratios are correspondingly lower (1.9:1).

More specific decoralive elements are recognized within each of the broad decorative method categories in the Henry Lake ceramic assemblage (Table 2). Starting with the utility wares, with the incised sherds, the decorative elements are simple straight and geometric designs (Figure 2a-c), probably Irom Maydelle Incised jars (Suhm and Jelks 1962:Plate 52). They include one horizontal incised jur with a $57 \mathrm{~mm}$ long strap handle attached on the vessel rim. Brushed sherds includc vertical brushing marks on the rim and body of Bullard Brushed jars (Suhm and Jelks 1962:Plate 11) (Figure 3), along with parallel brushing marks (Figure $4 a-b$ ), although a few have overlapping brushing on vessel bodies. One carinated bowl has a horizontal brushed body; the rim on this vessel likely has an engraved

Table 1. Henry Lake site decorated sherds.

\begin{tabular}{lccc}
\hline Decorative Method & Rim & Body & N \\
\hline Utility ware & 2 & 139 & 141 \\
Brushed & - & 11 & 11 \\
Brushed-incised & - & 2 & 2 \\
Brushed-punctated & 1 & 6 & 7 \\
Incised & - & 3 & 1 \\
Tool punctated & 1 & 2 & 3 \\
Fingernail punctated & 5 & 163 & 3 \\
Pinched & & & 168 \\
Subtotal & 7 & 11 & 18 \\
Fine ware & - & 2 & 2 \\
Engraved & 7 & 13 & 188 \\
Engraved-brushed & 12 & 176 & \\
Subtotal & & & \\
Totals & &
\end{tabular}

*handle 
Table 2. Decorative elements in the utility ware and fine ware ceramics from the Henry Lake site.

\begin{tabular}{|c|c|c|}
\hline Decorative Method & Decorative Element & $\mathrm{N}$ \\
\hline \multicolumn{3}{|l|}{ Utility ware } \\
\hline Incised & $\begin{array}{l}\text { horizuntal incised, rinı and handle } \\
\text { single straight incised line, body } \\
\text { opposcd incised lines, body } \\
\text { parallel incised lines, widely-spaced, body } \\
\text { parallel incised lines, closely-spaced, body } \\
\text { cross-hatched incised lines, body }\end{array}$ & $\begin{array}{l}1 \\
1 \\
1 \\
1 \\
1 \\
2\end{array}$ \\
\hline Brushed & $\begin{array}{l}\text { vertical brushed, rim } \\
\text { vertical brushed, body of carinated bowl } \\
\text { vertical brushed, body } \\
\text { overlapping brushed, body } \\
\text { horizontal brushed, body of carinated bowl } \\
\text { parallel brushed, body }\end{array}$ & $\begin{array}{r}2 \\
1 \\
4 \\
6 \\
1 \\
127\end{array}$ \\
\hline Brushed-Incised & $\begin{array}{l}\text { parallel brushed and overlapping parallel } \\
\text { incised lines, body } \\
\text { parallel brushed-incised, body } \\
\text { parallel brushed-curvilinear incised line, body }\end{array}$ & $\begin{array}{l}4 \\
2\end{array}$ \\
\hline Brushed-Punctated & $\begin{array}{l}\text { tool punctated row above vertical brushing, rim } \\
\text { tool punctated row above horicontal } \\
\text { brushing, body }\end{array}$ & $\begin{array}{l}1 \\
1\end{array}$ \\
\hline Punctated & $\begin{array}{l}\text { rows of tool punctations, body } \\
\text { rows of fingernail punctations, body }\end{array}$ & $\begin{array}{l}1 \\
3\end{array}$ \\
\hline Pinched & $\begin{array}{l}\text { vertical pinched rows, rim } \\
\text { vertical pinched rows, body }\end{array}$ & $\begin{array}{l}1 \\
2\end{array}$ \\
\hline
\end{tabular}

Fine ware

Engraved

broad horizontal engraved line, rim $\quad 1$

(cf. Hood Engraved)

single straight engraved line, body 3

parallel engraved lines, body 1

opposed engraved lines, body 1

broad curvilinear engraved lines, body 1

single curvilinear engraved line, body 2

scroll, rim 1

scroll, body 1

hour glass-shaped panel divider, body $\quad 2$

horizontal engraved line and hour glass- $\quad 3$

shaped panel divider, rim 


\section{Journal of Northeast Texas Archaeology}

Table 2. (Continued)

Decorative Method

Decorative Element

$\mathrm{N}$

\section{Fine ware}

arcs of curvilinear panel divider, rim

Engraved-Brushed

single horizontal engraved line above

horizontal brushing, body of carinated bowl

horizontal and diagonal engraved lines

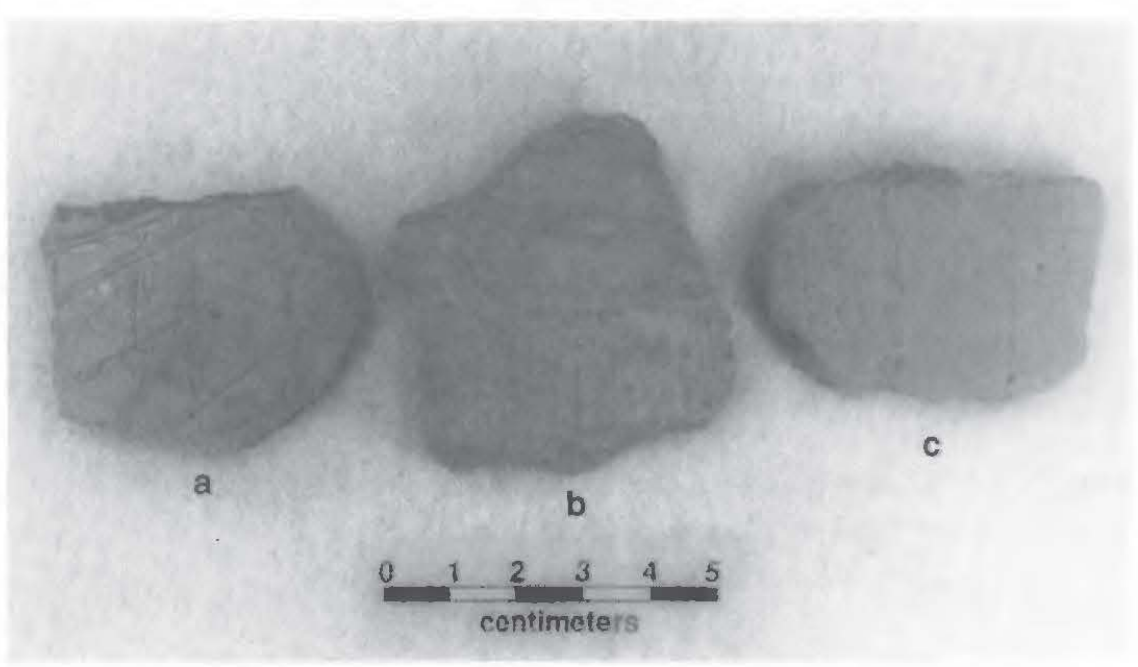

Figure 2. Incised body sherds: a-b, cross-hatched; c, parallel lines.

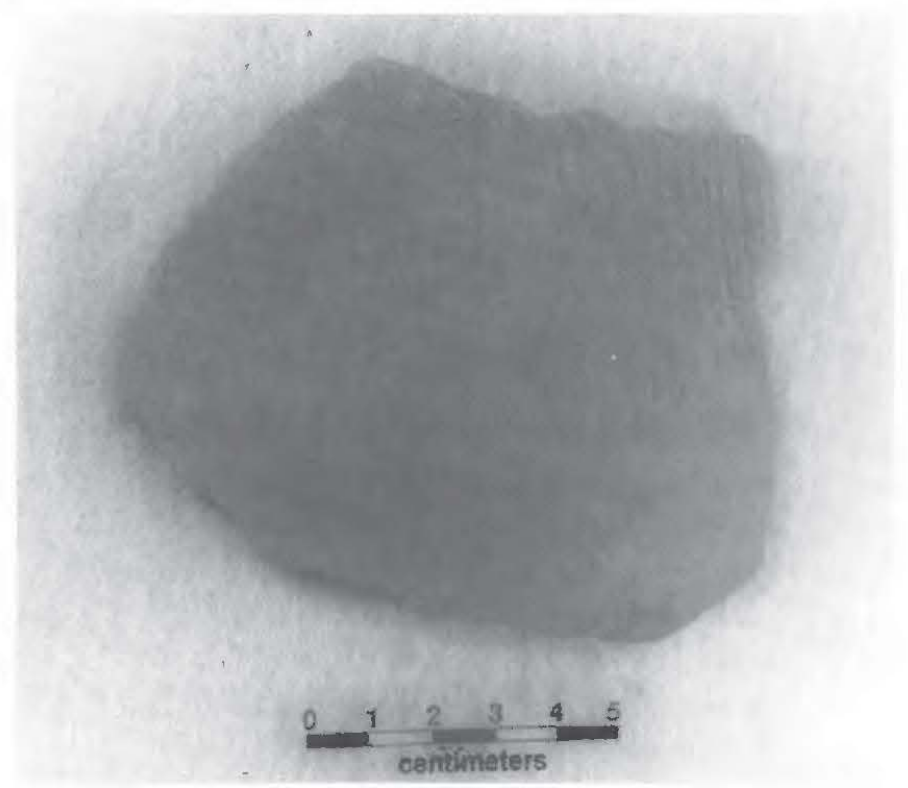

Figure 3. Vertical brushed body sherd. 


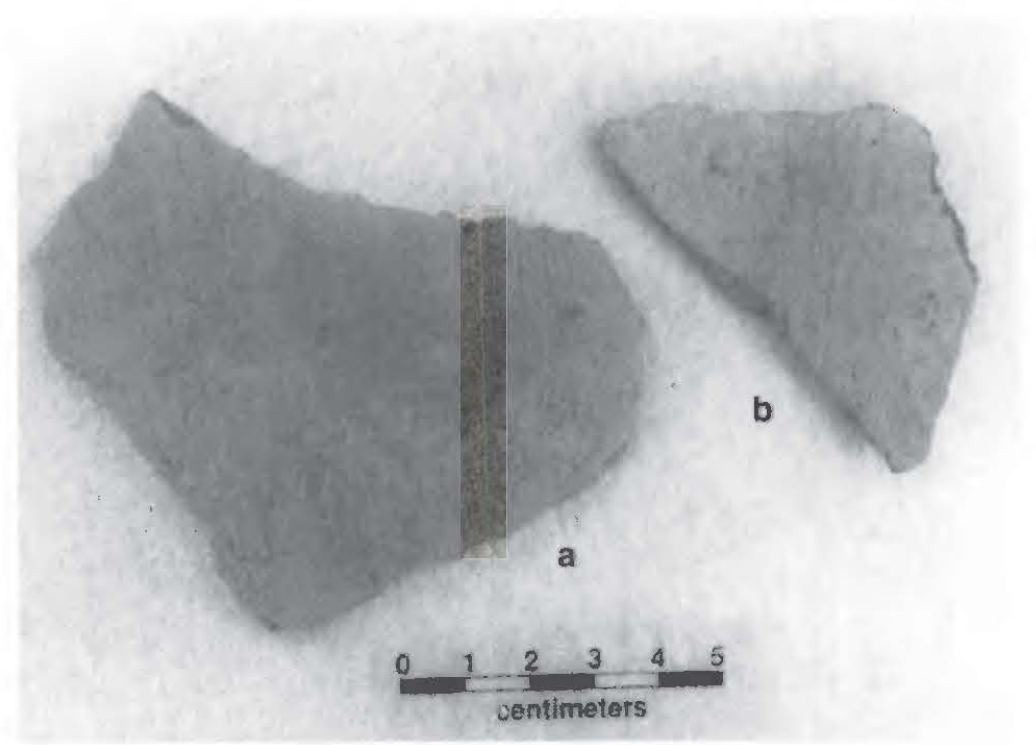

Figure 4. Parallel brushed body sherds.

motif (see below). Brushed-incised decorations at the Henry Lake site appear to be confined only to the body of utility ware vessels. In the case of the brushed-punctated sherds, they are from Bullard Brushed vessels (see Suhm and Jelks 1962:Plate $11 \mathrm{a}-\mathrm{b})$ with horizontal or vertical brushing marks on the vessel body and at least one row of tool punctations on the rim, beginning at the rim-body juncture (Table 2).

Tool and fingernail punctated sherds appear to be from vessels where rows of punctations covered the vessel body (see Table 2), but it is likely the case that rows of punctations occur on vessel rims as well, either as the sole decoration (Figure 5b-d), or in conjunction with brushed or brushed-incised vessel bodies. There are three Killough Pinched rim and body sherds in the Henry Lake decorated sherds (Figure 5a, e); rows of pinching typically covered the entirety of the exterior vessel surface of Killough Pinched jars (Suhm and Jelks 1962:Plate 46f-g, h, j).

A few of the engraved fine ware sherds have simple straight, geometric, or curvilinear elements, including one rim with a broad horizontal engraved line that is probably from a Hood Engraved effigy vessel (cf. Perttula 2008). The other engraved sherds are from Poynor Engraved bowls and carinated bowls (Suhm and Jelks 1962:Plate 62). Two have portions of engraved scrolls (Poynor Engraved, var. unspecified) (Figure 6b-d), two others have finely executed arcs of engraved lines forming ovals on a rim panel (Poynor Engraved, var. Cook) (Figure
$7 \mathrm{~b}$ ), and five have hour glass-shaped engraved and excised panel dividers that form negative ovals on a rim panel (Poynor Engraved, var. Hood) (cf. Perttula 2008) (Figures 6a, c and 7a).

The Caddo ceramics from the Henry Lake site are almost exclusively tempered with grog (99\%), namely crushed sherds and pieces of fired clay. Some $22.1 \%$ of the sherds also have pieces of crushed hematite or ferruginous sandstone that have been added to the paste, and another $3.2 \%$ have burned bone temper (see Appendix 1). The vessels from the site typically have a clay or silty paste, and only $6.3 \%$ of the sherds (primarily from plain body sherds or brushed vessel sherds) are from vessels with a sandy paste; these sherds likely came from vessels made with a naturally sandy clay. Another four sherds ( $4.2 \%$ of the detailed sherd sample) have a notable reddish-pink paste color, dubbed "pinkware" in the 41AN38 ceramic analysis; "pinkware" has been identified in a few other upper Neches River basin sites (Shawn Marceaux, personal communication, 2008). These particular "pinkware" sherds - three brushed sherds and a plain rim from the Henry Lake site-must be from vessels made from a distinctive but localized upper Neches River basin clay source.

The Henry Lake ceramic sherds are from vessels fired primarily in a reducing or low oxygen environment, particularly the fine wares $(92.8 \%)$. Among the plain sherds, $75 \%$ were fired in this manner, compared to $64.2 \%$ of the decorated utility wares (see Appendix 1). The utility ware 


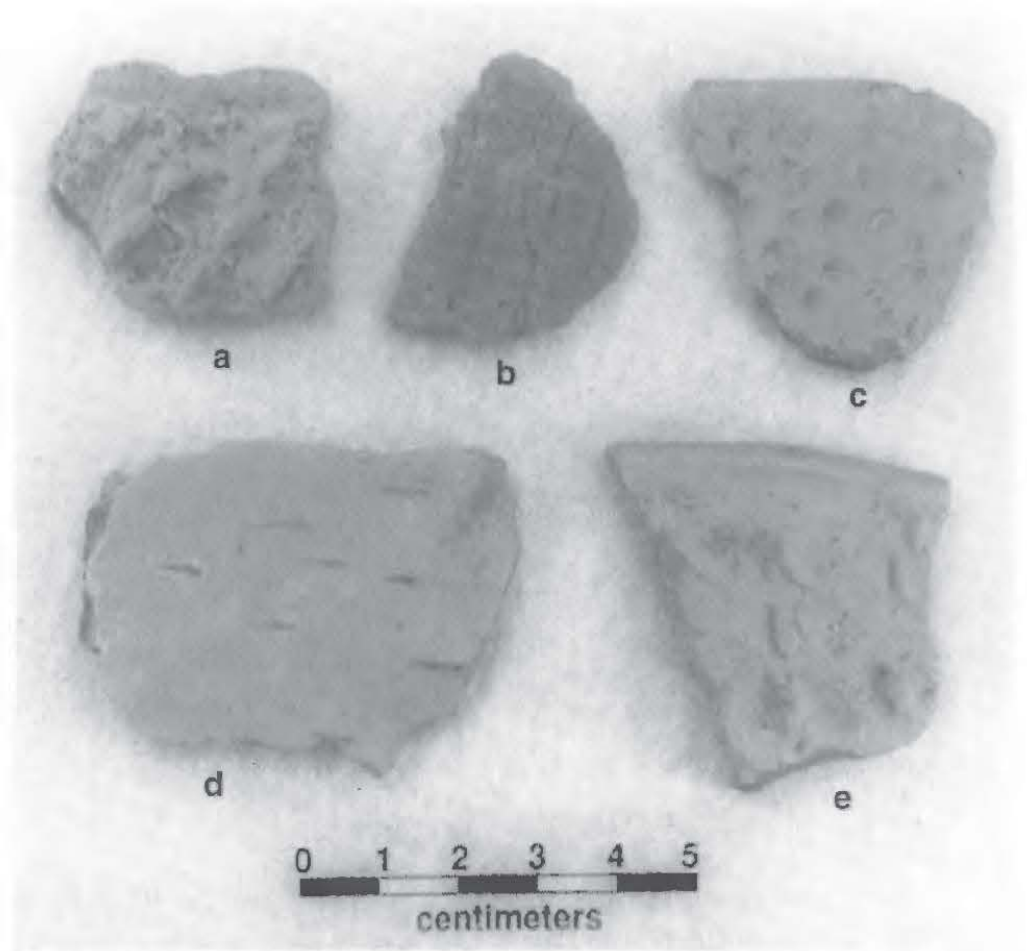

Figure 5. Punctated and pinched sherds: a, e, Killough Pinched; $b$, d, fingernail punctated; c, tool punctated.

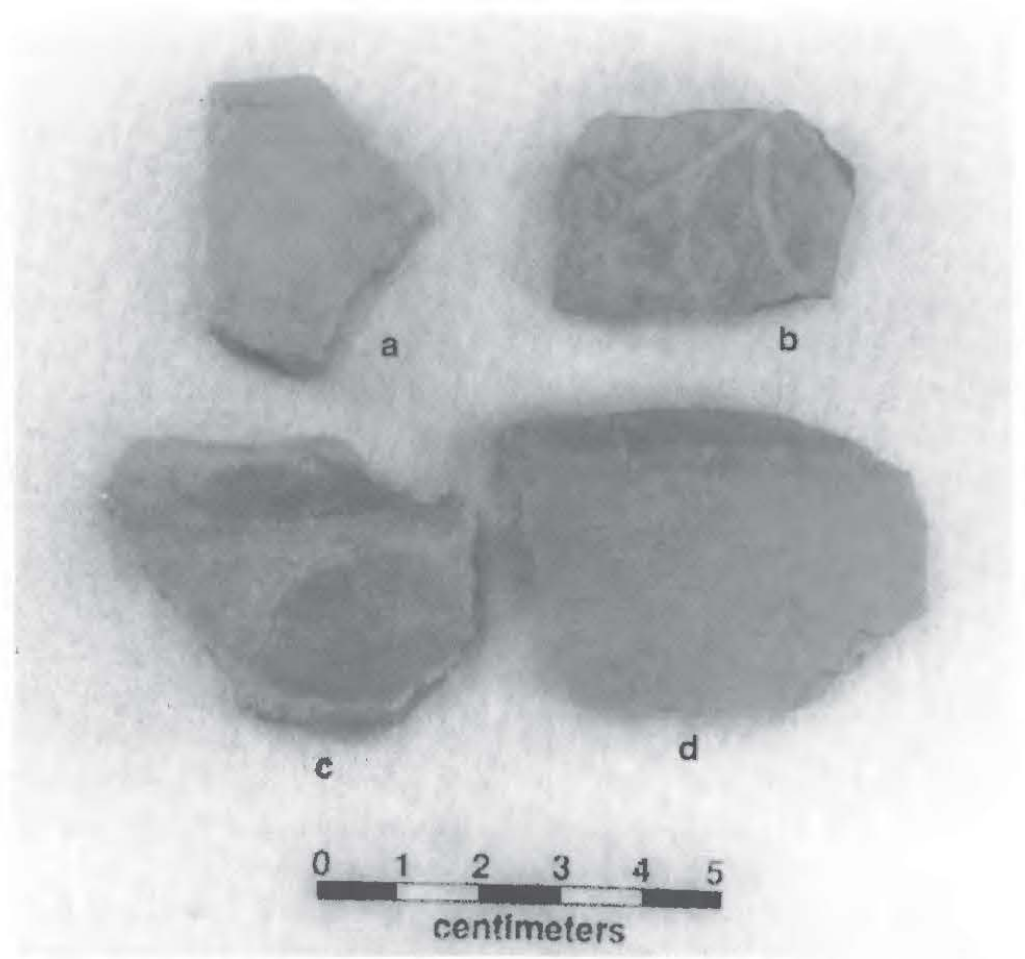

Figure 6. Engraved sherds: a, c, Poynor Engraved, var. Hood; b, d, engraved scrolls. 


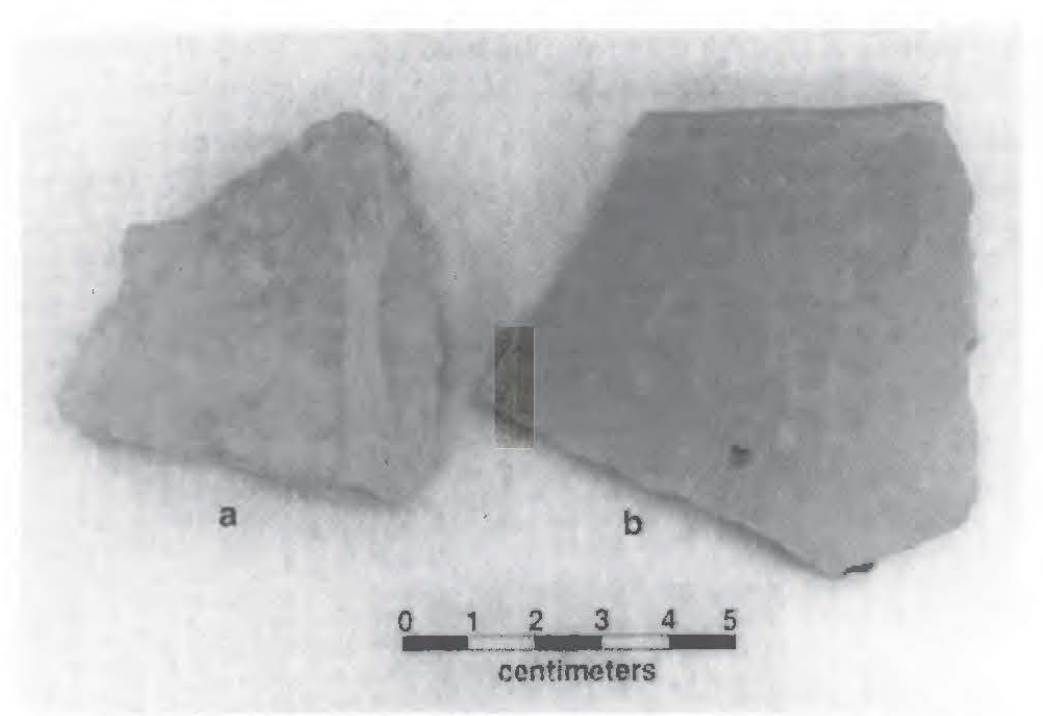

Figure 7. Poynor Engraved: a, Poynor Engraved, var. Hood; b, Poynor Engraved, var. Cook.

sherds were from vessels that were also commonly fired in a high oxygen or oxidizing environment $(9.4 \%)$ or were incompletely oxidized during firing $(26.4 \%)$.

Many of the plain and decorated sherds from the Henry Lake site have smoothed or burnished interior and/or exterior vessel surfaces (see Appendix I). In part, this is likely the product of the context in which the sherds had accumulated-a midden deposit that would have lessened the degradation of the surface condition of buried sherds-as well as the fact that most fine wares have interior and exterior smoothed or burnished surfaces and many of the utility ware vessels were smoothed on their interior vessel surfaces.

\section{UPPER NECHES RIVER BASIN CERAMIC TRADITIONS}

The Henry Lake site ceramics are from a Late Caddo Frankston phase (ca. A.D. 1400-1650) occupation. They include several varieties of Poynor Engraved, the principal fine ware of the Frankston phase (Suhm and Jelks 1962:123), a Hood Engraved or effigy vessel sherd, and sherds from several vessels of Maydelle Incised, Bullard Brushed, and Killough Pinched (see Table 2).

How does the decorated sherd assemblage from the Henry Lake site compare with other upper Neches River basin Caddo sites, and can that comparison provide more specific hints about when the site was occupied within the 250 year span of the Frankston phase? Comparisons of the composition of upper Neches River basin Caddo decorated sherd assemblages-and the temporal orderings and cultural affiliations they imply - are based on a mix of stylistic and technological attributes. These attributes include the percentage of brushed sherds in the decorated sherd sample from each site, the percentage of bone temper in the assemblages, the percentage of wet-paste decorations other than brushing (i.e., incised, punctated, appliqued, neckbanded, etc.), the plain/decorated sherd ratio (P/DR), and the brushed sherd/wet paste decorated sherd ratio (Table 3 ).

From these comparisons, five different groups of assemblages have been defined in a seriation of Lake Palestine sites (Anderson et al. 1974; Gilmore 1983) as well as other nearby and recently studied Caddo sites (i.e., $41 \mathrm{AN} 38$ and 4 ICE354) with large decorated sherd ceramic assemblages (Perttula and Nelson 2007; Perttula et al. 2007) (see Table 3). These five groups seem to reflect temporal changes due to the high frequency of Late Caddo Frankston phase decorated types, such as Poynor Engraved, Maydelle Incised, Bullard Brushed, Hume Engraved, and engraved effigy vessels, that are found in the Groups I-III sites-which includes the Henry Lake site - and the occurrence of Early and Middle Caddo types such as Canton Incised, Dunkin Incised, Holly Fine Engraved, Pennington Punctated-Incised in the Group IV and V sites; no Sanders phase pottery types (i.e., Sanders Engraved, Monkstown 
Table 3. Comparative sherd assemblage data from selected upper Neches River basin Caddo sites.

\begin{tabular}{lcccccc}
\hline Site & $\begin{array}{l}\text { No. of Dec. } \\
\text { Sherds }\end{array}$ & $\begin{array}{l}\text { \% } \\
\text { Brushed* }\end{array}$ & $\begin{array}{l}\text { \% bone- } \\
\text { temper }\end{array}$ & $\begin{array}{l}\text { \% Wet-paste } \\
\text { decorations }\end{array}$ & P/DR & $\begin{array}{l}\text { Brushed/Wet } \\
\text { paste ratio }\end{array}$ \\
\hline GROUP I & & & & & & \\
41CE354 & 474 & 82.7 & 3.1 & 8.9 & 0.20 & 8.14 \\
Henry Lake & $\mathbf{1 8 8}$ & $\mathbf{8 1 . 9}$ & $\mathbf{3 . 2}$ & $\mathbf{7 . 3}$ & $\mathbf{0 . 4 8}$ & $\mathbf{1 1 . 0}$ \\
Debro & 311 & 80.0 & $?$ & 10.3 & 0.14 & 7.75 \\
William & & & & & & \\
Sherman & 525 & 75.8 & $?$ & 16.2 & 0.44 & 4.68 \\
& & & & & & \\
GROUP II & & & & & & \\
Forest & & & & & & \\
Drive & 1693 & 68.6 & 21.9 & 0.56 & 3.12 \\
Halbert & 1757 & 65.8 & 2.6 & 26.3 & 0.70 & 2.51 \\
Woldert & 1730 & 62.7 & 0.0 & 28.8 & 0.72 & 2.19 \\
Ferguson & 4116 & 60.8 & $<1.0$ & 27.9 & 0.61 & 2.17
\end{tabular}

\section{GROUP III}

Tomato

$\begin{array}{lrrrrrr}\text { Patch } & 912 & 49.2 & ? & 41.7 & 1.50 & 1.21 \\ \text { 41AN38 } & 2435 & 35.9 & 6.7 & 38.0 & 1.40 & 0.91 \\ \text { Mitchell, D } & 54 & 32.1 & 0.0 & 33.3 & 1.37 & 1.50\end{array}$

\section{GROUP IV}

White Mule

$1404 \quad 18.5$

18.5
17.5

1.5

63.7

2.61

0.29

41HE139

40

8.1

65.0

2.51

0.33

GROUP V

Mitchell, A-C

$56 \quad 1.3$

12.0

65.7

1.71

0.03

$\mathrm{P} / \mathrm{DR}=$ plain/decorated sherd ratio

*\% brushed represents the percentage of brushed sherds among all the decorated sherds.

Fingernail Impressed, Maxey Noded Redware) were recovered in any of these sites. Furthermore, it has been shown in several other ceramic studies in northeastern Texas that the proportion of brushed sherds in decorated sherd assemblages steadily increases through time, beginning after ca. A.D. 1250 (and after the principal Early Caddo occupation at the George C. Davis site), and by the late 17 th and early 18 th centuries Caddo sites are known in the Neches and Angelina river basins where brushed sherds account for more than $50 \%$ and as much as $90 \%$ of all the decorated pottery.

Of note is the generally low use of bone-tempered pottery in upper Neches River basin Caddo pottery in each of the five site/assemblage groupings (see Table 3 ). The tradition of manufacturing grog-tempered vessels is a strong and long-lasting one in this region, and the ceramic assemblage from the Henry Lakc site is certainly part of that same tradition.

If the sherd assemblage data from the Lake Palestine area sites have chronological significance, and it is suspected they do given the discussion above regarding the kinds of engraved fine wares that are present at each of the sites as well as the changing proportions of brushed pottery (see Table 3 ), then it is possible to seriate the decorated ceramic sherd assemblage fron the Henry Lake site, 
and establish its age. Key in this respect is the very high proportion of brushed pottery $(81.9 \%)$ in the Henry Lake site ceramic assemblage (see Table 3). This points to the likelihood that the Caddo occupation at Henry Lake was one of the youngest components in the Group I Frankston phase sites. The absence of any Patton Engraved pottery, the principal fine ware in post-A.D. 1650 Allen phase sites in the upper Neches Rive basin, in the engraved fine wares from the Henry Lake site, may provide an upper limit to the age of the Caddo occupation here; Patton Engraved pottery is present, and relatively abundant, only in the youngest Group I site: 41CE354 (Perttula and Nelson 2007). Taken together, the very high proportions of brushed utility wares at the Henry Lake site, the dominance of Poynor Engraved sherds in the fine wares, and the absence of post-A.D. 1650 Patton Engraved sherds, suggest that this Caddo occupation probably took place from ca. A.D. 1600-1650, near the end of the Frankston phase, well prior to any sustained contact between the upper Neches River basin Caddo groups and Europeans.

\section{REFERENCES CITED}

Anderson, K. M., K. Gilmore, O. R. McCormick, III, and E. P. Morenon

1974 Archaeological Investigations at Lake Palestine, Texas. Contributions in Anthropology No. 11. Department of Anthropology, Southern Methodist University, Dallas.

Gilmore, K.

1983 Caddoan Interaction in the Neches Valley, Texas. Reprints in Anthropology, No. 27. J\&L Reprint Company, Lincoln. Nebraska.
Perttula, T. K.

20088 Trends and Varieties in Late Caddo and Historic Caddo Fine Ware Pottery Types in the Upper Neches River Basin. Journal of Northeast Texas Archaeology 28:51-55.

Perttula, T. K. (editor)

2005 Archeological Investigations at the Pilgrim's Pride Site (41CP304), a Titus Phase Community in the Big Cypress Creek Basin. 2 Vols. Report of Investigations No. 30. Archeological \& Environmental Consultants, LLC, Austin.

Perttula, T. K. and B. Nelson

2007 Archeological Survey Investigations and Test Excavations at 4ICE354 at the North and South Lake areas of the H.R.C. Cherokee Tree Farm, L. P. Project, Cherokee County. Texas. Report of Investigations No. 80. Archeological \& Environmental Consultants, LLC, Austin.

Perttula, T. K., D. B. Kelley, D. E. Wilson, and B. M. Albert 2007 Final Research Design for Data Recovery Excavations at 4IAN38, Anderson County. Texas. Coastal Environments, Inc. and Archeological \& Environmental Consultants, LLC. Baton Rouge and Austin.

Suhm, D. A. and E. B. Jelks (editors)

1962 Handbook of Texas Archeology: Type Descriptions. Special Publication No. 1, Texas Archeological Society, and Bulletin No. 4, Texas Memorial Museum, Austin.

Swanson, G. and T. Middlebrook

1996 The Henry Lake Site (41CE324). Paper presented at the 1996 East Texas Archeological Conference, Tyler. Texas.

Teltser, P. A.

1993 An Analytic Strategy for Studying Assemblage-Scale Ceramic Variation: A Case Study from Southeast Missouri. American Antiquity 58(3):530-543. 


\section{APPENDIX 1}

Attribute Analysis of a Sample of Plain and Decorated Sherds from the Henry Lake Site (41CF.324)

\begin{tabular}{|c|c|c|c|c|c|c|c|}
\hline Lot No. & $\begin{array}{l}\text { Sherd } \\
\text { Type }\end{array}$ & Temper & Puste & $\mathrm{FC}$ & $\mathrm{ST}$ & Th & Decoration \\
\hline 1 & rim & $\mathrm{g}-\mathrm{h}$ & $\mathrm{c}$ & $\mathrm{F}$ & I/E SM & 6.7 & plain. Bottle \\
\hline 1 & rim & $g-h$ & $c$ & $\mathrm{~F}$ & - & 6.4 & plain, D-FL \\
\hline 1 & rim & $\mathrm{g}$ & $c$ & $\mathrm{G}$ & I/E SM & 8.2 & plain, D-FL \\
\hline 1 & rim & $g-h$ & $\mathrm{C}$ & $\wedge$ & I/E SM & 6.5 & plain, D-RO, ext f \\
\hline 2 & rim & g & $\mathrm{c}$ & $\wedge$ & I B & 7.7 & plain. D-FL: pinkware \\
\hline 1 & body & $\mathrm{g}$ & $\mathrm{c}$ & $G$ & I SM & 5.6 & plain \\
\hline 1 & body & $\mathrm{g}$ & $c$ & $\Gamma$ & I SM & 6.5 & plain \\
\hline 1 & body & $g-h$ & c & $\mathrm{E}$ & - & 7.7 & plain \\
\hline 1 & body & $\mathrm{g}$ & c & C & I/E SM & 6.5 & plain \\
\hline 1 & body & $\mathrm{g}$ & c & $\mathrm{H}$ & E SM & 5.2 & plain \\
\hline 1 & body & $\mathrm{g}$ & c & $G$ & I/E SM & 7.4 & plain \\
\hline 1 & body & $\mathrm{g}$ & $c$ & $\mathrm{H}$ & I SM & 7.1 & plain \\
\hline 1 & body & $\mathrm{g}$ & $c$ & $F$ & I SM & 6.5 & plain \\
\hline 1 & body & $\mathrm{g}$ & $c$ & $G$ & I/E SM & 6.3 & plain \\
\hline 1 & body & $g-h$ & $c$ & $\mathrm{G}$ & I/E SM & 7.0 & plain \\
\hline 1 & body & $\mathrm{g}$ & $\mathrm{c}$ & $\mathrm{G}$ & I/E SM & 6.9 & plain \\
\hline 1 & body & $\mathrm{g}$ & $c$ & $\mathrm{H}$ & $\begin{array}{l}\mathrm{EB} / \\
\mathrm{I} \text { SM }\end{array}$ & 5.6 & plain \\
\hline 1 & body & $\mathrm{g}$ & c & $\mathrm{G}$ & $\mathrm{I} / \mathrm{F} \mathrm{B}$ & 8.0 & plain \\
\hline 1 & body & $\mathrm{g}$ & $\mathrm{c}$ & $\mathrm{G}$ & E B & 7.9 & plain \\
\hline 1 & body & $\mathrm{g}$ & SP & $\mathrm{E}$ & I/E SM & 8.0 & plain \\
\hline 1 & body & $\mathrm{g}$ & $c$ & $\mathrm{~F}$ & I/E SM & 6.9 & plain \\
\hline 2 & body & $\mathrm{g}$ & $c$ & G & $1 \mathrm{SM}$ & 6.5 & plain \\
\hline 2 & body & g-o & $\mathrm{c}$ & $F$ & E SM & 6.0 & plain \\
\hline 2 & body & $\mathrm{g}$ & $\mathrm{c}$ & G & I SM & 10.7 & plain \\
\hline 1 & base & $\mathrm{g}$ & $\mathrm{c}$ & $\mathrm{B}$ & ESM & 11.6 & plain \\
\hline 1 & base & $g-h$ & SP & $\mathrm{K}$ & ESM & 14.0 & plain \\
\hline 1 & base & $g$ & c & G & & 12.5 & plain \\
\hline 2 & base & $\mathrm{g}$ & $c$ & $\mathrm{~B}$ & - & 9.6 & plain \\
\hline 1 & $\begin{array}{l}\text { strap } \\
\text { handle }\end{array}$ & $\mathrm{g}-\mathrm{h}$ & $\mathrm{c}$ & B & - & 8.4 & $\begin{array}{l}\text { horizontal incised line } \\
\text { below handle } \\
\text { attachment; handle is plain }\end{array}$ \\
\hline 1 & body & $\mathrm{g}$ & $\mathrm{c}$ & B & $1 \mathrm{SM}$ & 7.5 & single straight incised line \\
\hline 1 & body & $\mathrm{g}$ & c & $\mathrm{F}$ & & 7.1 & opposed incised lines \\
\hline 1 & body & $g-b-h$ & $\mathrm{c}$ & $\mathrm{B}$ & - & 96 & $\begin{array}{l}\text { parallel incised lines, } \\
\text { widely-spaced }\end{array}$ \\
\hline 1 & body & $\mathrm{g}$ & $\mathrm{c}$ & $\mathrm{C}$ & I SM & 7.0 & cruss-hatched incised lines \\
\hline 1 & body & $g$ & $c$ & B & I SM & 7.6 & cross-hatched incised lines \\
\hline 1 & rim & $\mathrm{g}$ & $c$ & $\mathrm{E}$ & I SM & 6.5 & $\begin{array}{l}\text { 6+ rows of tool punctations: } \\
\text { EV-RO }\end{array}$ \\
\hline 1 & body & $\mathrm{g}$ & c & $\mathrm{G}$ & I SM & 7.3 & $3+$ fingernail punctated rows \\
\hline
\end{tabular}




\begin{tabular}{|c|c|c|c|c|c|c|c|}
\hline Lot No. & $\begin{array}{l}\text { Sherd } \\
\text { Type }\end{array}$ & Temper & Paste & $\mathrm{FC}$ & ST & Th & Decoration \\
\hline 1 & $\mathrm{rim}$ & $g$ & c & $\mathrm{H}$ & - & 10.9 & $\begin{array}{l}\text { vertical pinched rows; EV- } \\
\text { RO }\end{array}$ \\
\hline 1 & body & $\mathrm{g}$ & $c$ & $\mathrm{~F}$ & $1 \mathrm{SM}$ & 8.7 & vertical pinched rows \\
\hline 1 & rim & g & c & B & - & 7.6 & vertical brushed: D-RO \\
\hline 1 & rim & $\mathrm{g}$ & $\mathrm{c}$ & B & - & 7.9 & vertical brushed; EV-RO \\
\hline 1 & body & $\mathrm{g}$ & c & G & I SM & 8.9 & vertical brushed \\
\hline 1 & body & $\mathrm{g}$ & c & K & $\mathrm{I} / \mathrm{E} \mathrm{SM}$ & 8.0 & vertical brushed \\
\hline 1 & body & $g-h$ & c & A & I SM & 8.2 & $\begin{array}{l}\text { overlapping brushed; } \\
\text { pinkware }\end{array}$ \\
\hline 1 & body & $\mathrm{g}$ & $\mathrm{c}$ & $\mathrm{F}$ & - & 6.2 & overlapping brushed \\
\hline 1 & body & $\mathrm{g}-\mathrm{h}$ & c & $\mathrm{D}$ & I SM & 7.0 & overlapping brushed \\
\hline 1 & body & g & c & $\mathrm{E}$ & I SM & 6.3 & parallel hrushed \\
\hline 1 & body & g & $\mathrm{c}$ & B & - & 9.1 & parallel brushed \\
\hline 1 & body & $\mathrm{g}$ & c & $\mathrm{E}$ & I SM & 6.6 & parallel brushed \\
\hline 1 & body & $g-h$ & c & $\mathrm{C}$ & I SM & 8.7 & parallel brushed \\
\hline 1 & body & g & $\mathrm{c}$ & $\mathrm{B}$ & - & 7.2 & parallel brushed \\
\hline 1 & body & g & $\mathrm{c}$ & G & $1 \mathrm{SM}$ & 9.1 & parallel brushed \\
\hline 1 & body & $\mathrm{g}$ & c & $\mathrm{F}$ & I SM & 7.5 & parallel brushed \\
\hline 1 & body & $\mathrm{g}$ & $\mathrm{c}$ & $\mathrm{F}$ & I SM & 7.0 & parallel brushed \\
\hline 1 & body & $\mathrm{g}$ & $\mathrm{c}$ & A & I SM & 8.9 & parallel brushed; pinkware \\
\hline 1 & body & $g$ & c & $\mathrm{F}$ & - & 9.0 & parallel brushed \\
\hline 1 & body & $\mathrm{g}$ & c & $\mathrm{F}$ & - & 7.9 & parallel brushed \\
\hline 1 & body & $g-h$ & c & $\mathrm{C}$ & - & 6.3 & parallel brushed \\
\hline 1 & body & $g$ & c & B & I SM & 9.2 & parallel brushed \\
\hline 1 & body & b & c & $\mathrm{B}$ & - & 6.2 & parallel brushed \\
\hline 1 & body & g & SP & B & I SM & 6.9 & parallel brushed \\
\hline 1 & body & $\mathrm{g}$ & $\mathrm{c}$ & B & I SM & 9.0 & parallel brushed \\
\hline 1 & body & $\mathrm{g}$ & c & B & I SM & 9.2 & parallel brushed \\
\hline 1 & body & $g$ & $\mathrm{c}$ & A & - & 10.2 & parallel brushed \\
\hline 1 & body & $g$ & c & $\mathrm{E}$ & - & 5.8 & parallel brushed \\
\hline 1 & body & $\mathrm{g}$ & c & $\mathrm{G}$ & I SM & 6.9 & parallel brushed \\
\hline 1 & body & $\mathrm{g}$ & $\mathrm{c}$ & $\mathrm{F}$ & - & 11.2 & parallel brushed \\
\hline 1 & body & $g-h$ & SP & G & I SM & 9.3 & parallel brushed \\
\hline 1 & body & $\mathrm{g}$ & $c$ & $\mathrm{E}$ & I SM & 9.3 & parallel brushed \\
\hline 1 & body & $g-h$ & $c$ & A & - & 8.4 & parallel brushed \\
\hline 1 & body & $\mathrm{g}$ & $\mathrm{c}$ & A & - & 7.6 & parallel brushed; pinkware \\
\hline 2 & body & $\mathrm{g}$ & $c$ & $\mathrm{~K}$ & - & 7.5 & parallel brushed \\
\hline 2 & body & $g-h-b$ & SP & $\mathrm{F}$ & I SM & 7.1 & vertical brushing on body; $\mathrm{CB}$ \\
\hline 1 & body & $\mathrm{g}$ & c & B & I SM & 9.7 & $\begin{array}{l}\text { parallel brushed-overlapping } \\
\text { incised lines }\end{array}$ \\
\hline 1 & body & $\mathrm{g}$ & c & $\mathrm{L}$ & I SM & 7.4 & $\begin{array}{l}\text { parallel brushed-overlapping } \\
\text { parallel incised lines }\end{array}$ \\
\hline 1 & body & $\mathrm{g}$ & $\mathrm{c}$ & $F$ & - & 7.6 & $\begin{array}{l}\text { parallel brushed-overlapping } \\
\text { parallel incised lines }\end{array}$ \\
\hline
\end{tabular}




\begin{tabular}{|c|c|c|c|c|c|c|c|}
\hline Lot No. & $\begin{array}{l}\text { Sherd } \\
\text { Type }\end{array}$ & Temper & Paste & $\mathrm{FC}$ & ST & Th & Decoration \\
\hline 1 & body & $\mathrm{g}$ & $\mathrm{c}$ & I & I SM & 9.0 & parallel brushed-incised \\
\hline 1 & body & $\mathrm{g}$ & $\mathrm{c}$ & $\mathrm{F}$ & I SM & 7.5 & parallel brushed-incised \\
\hline 1 & body & $\mathrm{g}$ & $\mathrm{c}$ & $\mathrm{D}$ & - & 6.8 & $\begin{array}{l}\text { parallel brushed-curvilinear } \\
\text { incised line }\end{array}$ \\
\hline 1 & body & $\mathrm{g}$ & $\mathrm{c}$ & $\mathrm{H}$ & I SM & 6.9 & $\begin{array}{l}\text { parallel brushed-curviline:ar } \\
\text { incised line }\end{array}$ \\
\hline 1 & body & $\mathrm{g}$ & c & B & I SM & 5.7 & $\begin{array}{l}\text { tool punctated ruw above } \\
\text { vertical brushing }\end{array}$ \\
\hline 1 & body & $\mathrm{g}$ & $c$ & G & - & 7.6 & $\begin{array}{l}\text { tool punctated row above } \\
\text { horizontal brushing }\end{array}$ \\
\hline 1 & rim & $\mathrm{g}$ & $\mathrm{c}$ & $\mathrm{F}$ & I/E SM & 6.5 & $\begin{array}{l}\text { horizontal engraved line: } \\
\text { D-FL; effigy vessel }\end{array}$ \\
\hline 1 & rim & $g-h$ & c & $\mathrm{F}$ & I/E SM & 7.2 & $\begin{array}{l}\text { engraved scroll element: } \\
\text { Poynor Engraved, D-RO }\end{array}$ \\
\hline 1 & rim & g-h & $\mathrm{c}$ & $\mathrm{F}$ & $\mathrm{I} / \mathrm{E} \mathrm{B}$ & 7.4 & $\begin{array}{l}\text { oval-shaped engraved arc: } \\
\text { Poynor Engraved, rar: Conk, } \\
\text { D-RO, ext } \mathrm{f}\end{array}$ \\
\hline 1 & rim & g-h & $\mathrm{c}$ & $\mathrm{F}$ & I/E SM & 6.8 & $\begin{array}{l}\text { oval-shaped engraved arcs: } \\
\text { Poynor Engraved, var. } \\
\text { Conk; D-RO }\end{array}$ \\
\hline 1 & rim & $\mathrm{g}$ & c & A & I/E SM & 3.3 & $\begin{array}{l}\text { horizontal engraved and } \\
\text { hour glass-shaped column; } \\
\text { Poynor Engraved. var: } \\
\text { Hood, D-RO }\end{array}$ \\
\hline 1 & rim & $\mathrm{g}$ & $\mathrm{c}$ & $\mathrm{F}$ & I/E SM & 5.7 & $\begin{array}{l}\text { horizontal engraved line and } \\
\text { hour glass-shaped column; } \\
\text { Poynor Engraved, var. Hood. } \\
\text { D-RO. ext f }\end{array}$ \\
\hline 2 & rim & $\mathrm{g}$ & $\mathrm{c}$ & $\mathrm{F}$ & I/E SM & 7.2 & $\begin{array}{l}\text { engraved hour glass-shaped } \\
\text { column; Poynor Engraved. } \\
\text { var. Hood; D-RO, ext } \mathrm{f}\end{array}$ \\
\hline I & body & $g$ & c & $\mathrm{H}$ & I/E SM & 7.9 & $\begin{array}{l}2+\text { broad curvilinear } \\
\text { engraved lines }\end{array}$ \\
\hline 1 & body & $\mathrm{g}$ & SP & $\mathrm{F}$ & I/E SM & 6.6 & $\begin{array}{l}\text { single curvilinear engraved } \\
\text { line }\end{array}$ \\
\hline 1 & body & $g$ & $c$ & B & I/E SM & 5.7 & $\begin{array}{l}\text { engraved scroll element: } \\
\text { Poynor Engraved }\end{array}$ \\
\hline 1 & body & $\mathrm{g}$ & c & $\mathrm{H}$ & E SM & 7.6 & $\begin{array}{l}\text { excised hour glass-shaped } \\
\text { column; Poynor Engraved, } \\
\text { var: Hood }\end{array}$ \\
\hline 1 & body & $g-h$ & c & $\mathrm{F}$ & I/E SM & 7.9 & $\begin{array}{l}\text { excised hour glass-shaped } \\
\text { column; Poynor Engraved. } \\
\text { lar. Hood }\end{array}$ \\
\hline
\end{tabular}




\begin{tabular}{|c|c|c|c|c|c|c|c|}
\hline Lot No. & $\begin{array}{l}\text { Sherd } \\
\text { Type }\end{array}$ & Temper & Paste & $\mathrm{FC}$ & ST & Th & Decoration \\
\hline 1 & body & $g-h$ & c & G & I/E SM & 7.4 & $\begin{array}{l}\text { single horizontal engraved } \\
\text { line above horizontal } \\
\text { brushing on body; } \mathrm{CB}\end{array}$ \\
\hline 1 & body & g-h-o & c & $\mathrm{F}$ & E B & 6.6 & $\begin{array}{l}\text { horizontal and diagonal } \\
\text { engraved lines and opposed } \\
\text { brushing on body; Poynor } \\
\text { Engraved, CB }\end{array}$ \\
\hline
\end{tabular}

*ST=surface treatment: $1 / \mathrm{E}=$ interior/exterior: $\mathrm{SM}=$ smoothed: $\mathrm{B}=$ burnished FC=firing condition (see Teltser 1993: Figure 2; Pertula 2005:Figure 5-30).

$\mathrm{Th}=$ thickness, in $\mathrm{mm}$

$\mathrm{D}=$ direct rim; $\mathrm{EV}=$ =verted; $\mathrm{INV}=$ inverted; $\mathrm{RO}=$ rounded lip; $\mathrm{FL}$ =flat lip; ext $\mathrm{f}=$ exterior folded lip $\mathrm{CB}=$ carinated bowl

$\mathrm{g}=\mathrm{grog} ; \mathrm{h}=$ hematite; $\mathrm{b}=$ bone: $\mathrm{o}=$ charred organic material; $\mathrm{SP}=$ sandy paste 